\title{
Coal Underlying Federal Lands in the Gulf of Mexico Coastal Plain
}

The U.S. Geological Survey (USGS) assessed selected coal beds or coal zones in northeastern Texas, central Texas, and the Sabine Uplift regions of Texas and Louisiana (fig. 1) as part of the National Coal Resource Assessment (NCRA). The purposes of the NCRA were (1) to digitally assess original and remaining (unmined) resources (Wood and others, 1983) for selected coal beds and zones that will be used in the near future, (2) to create publicly available stratigraphic and geochemical data in a geographic information system (GIS) framework, and (3) to provide geologic and geochemical information for the primary coal resources that will supply a major part of the Nation's energy needs during the next few decades. The NCRA was limited to five priority regions; the Texas and Louisiana coals are in the Gulf of Mexico Coastal Plain priority region.

The USGS assessment of coal resources in the Gulf of Mexico Coastal Plain was conducted in collaboration with the Louisiana Geological Survey; the University of Texas at Austin, Bureau of Economic Geology; the Railroad Commission of Texas; and the Louisiana Department of Natural Resources, Office of Conservation, Injection and Mining Division.

\section{Resources Underlying Federal Lands}

Agencies managing Federal surface lands within the Gulf of Mexico Coastal Plain coal-bearing region include the U.S.

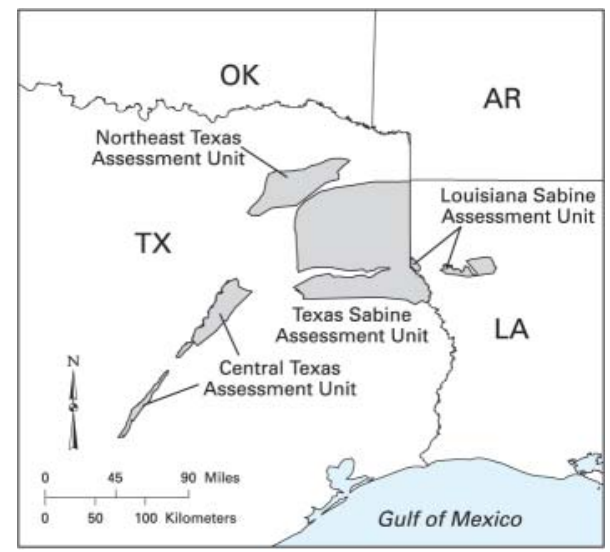

Figure 1. Location of coal resource assessment units in the Gulf of M exico Coastal Plain, one of five regions assessed by the U.S. Geological Survey in the National Coal Resource Assessment.
Department of Defense, U.S. Department of Agriculture Forest Service, U.S. Fish and Wildlife Service, and Bureau of Indian Affairs. The United States does not have title to all the lands within the Federal tracts shown in figure 2 . In some areas, notably legislatively proclaimed administrative boundaries of National Forests, Federal and private surface ownerships are intermixed. In other areas, such as small National Wildlife Refuges, the surface may be managed through easements rather than outright Federal ownership. Most of the land to which the United States holds title within the Gulf of Mexico Coastal Plain was acquired from other owners and may be subject to different public land laws and regulations than land retained from the original public domain. If the mineral estate was acquired along with the surface, it is managed by the U.S. Bureau of Land Management (BLM). In addition to the federally managed surface shown in figure 2, there are scattered tracts of federally acquired mineral estate, also managed by BLM, underlying non-Federal surface.
At present, there is no systematic inventory of Federal mineral ownership in the central and eastern United States, including the Gulf of Mexico Coastal Plain. Inventories of critical areas are underway by land management agencies. Initial indications are that about half of the Federal surface estate in the Gulf of Mexico Coastal Plain is underlain by federally owned minerals.

Estimated tonnages of coal underlying selected areas of the federally managed surface shown in figure 2 were calculated in a GIS environment by using maps showing the subsurface thickness of selected coal beds or zones. Gross estimates of Federal coal ownership provided by land management agencies were applied to the calculated tonnages to estimate the amount of federally owned coal within these tracts. The estimated coal resource tonnages for the Gulf of Mexico Coastal Plain coalbearing region do not include coal that underlies Federal lands outside of the areas assessed for the NCRA or coal in the Federal mineral estate that underlies nonFederal surface lands.

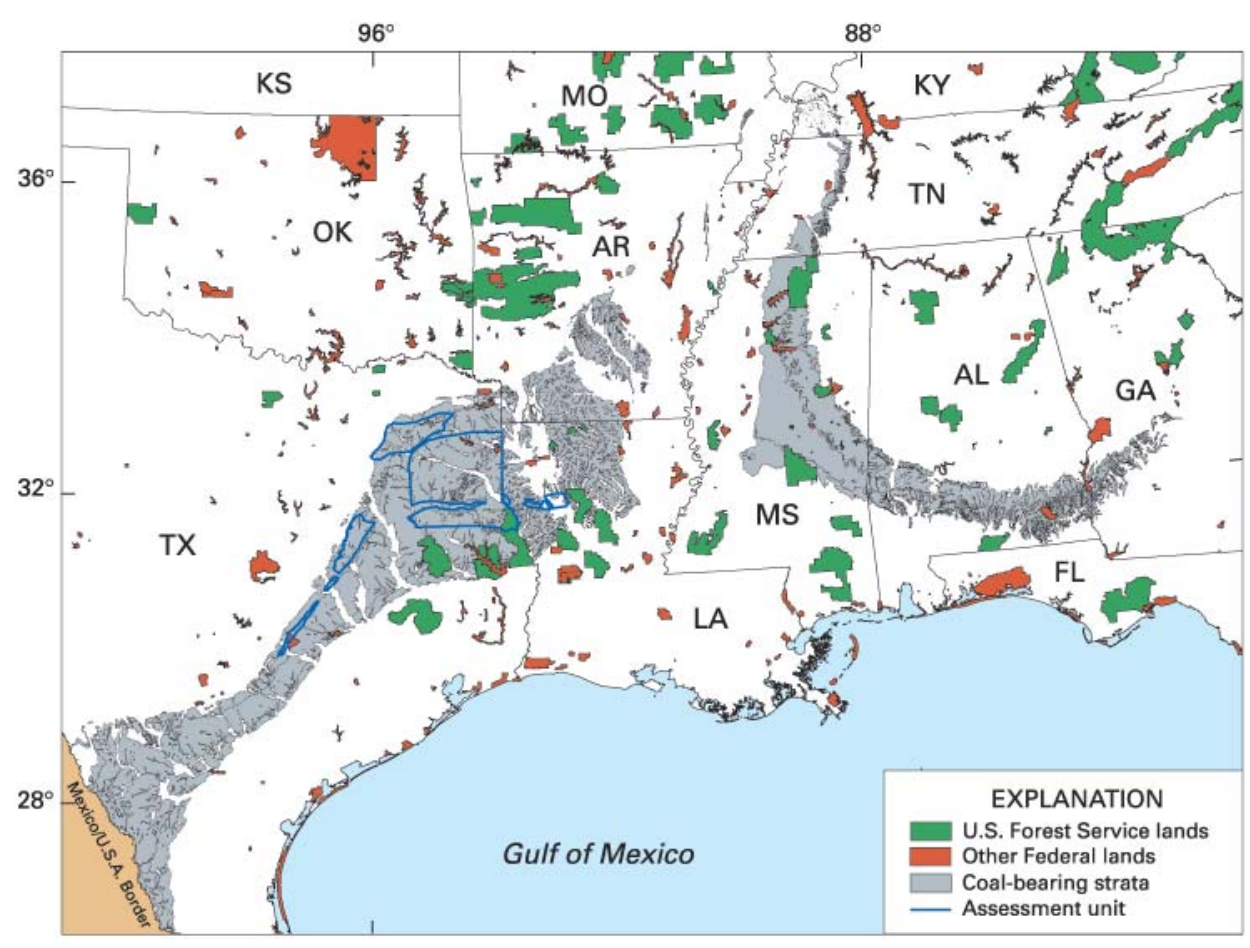

Figure 2. Distribution of Federal lands (from U.S. Geological Survey, 2000) and outcrop of coalbearing strata in the Gulf of M exico Coastal Plain. Blue lines indicate areas assessed for the National Coal Resource Assessment (fig. 1). 
Figure 3 summarizes resource estimates and quality of coals underlying Federal lands within the assessment units of central Texas and the Sabine Uplift area of Texas; these data are from the Gulf of Mexico Coastal Plain Coal Region Assessment Team (in press). The approximately 11 billion short tons estimated to underlie the federally managed surface tracts, including non-Federal coal and surface ownership as outlined above, represents

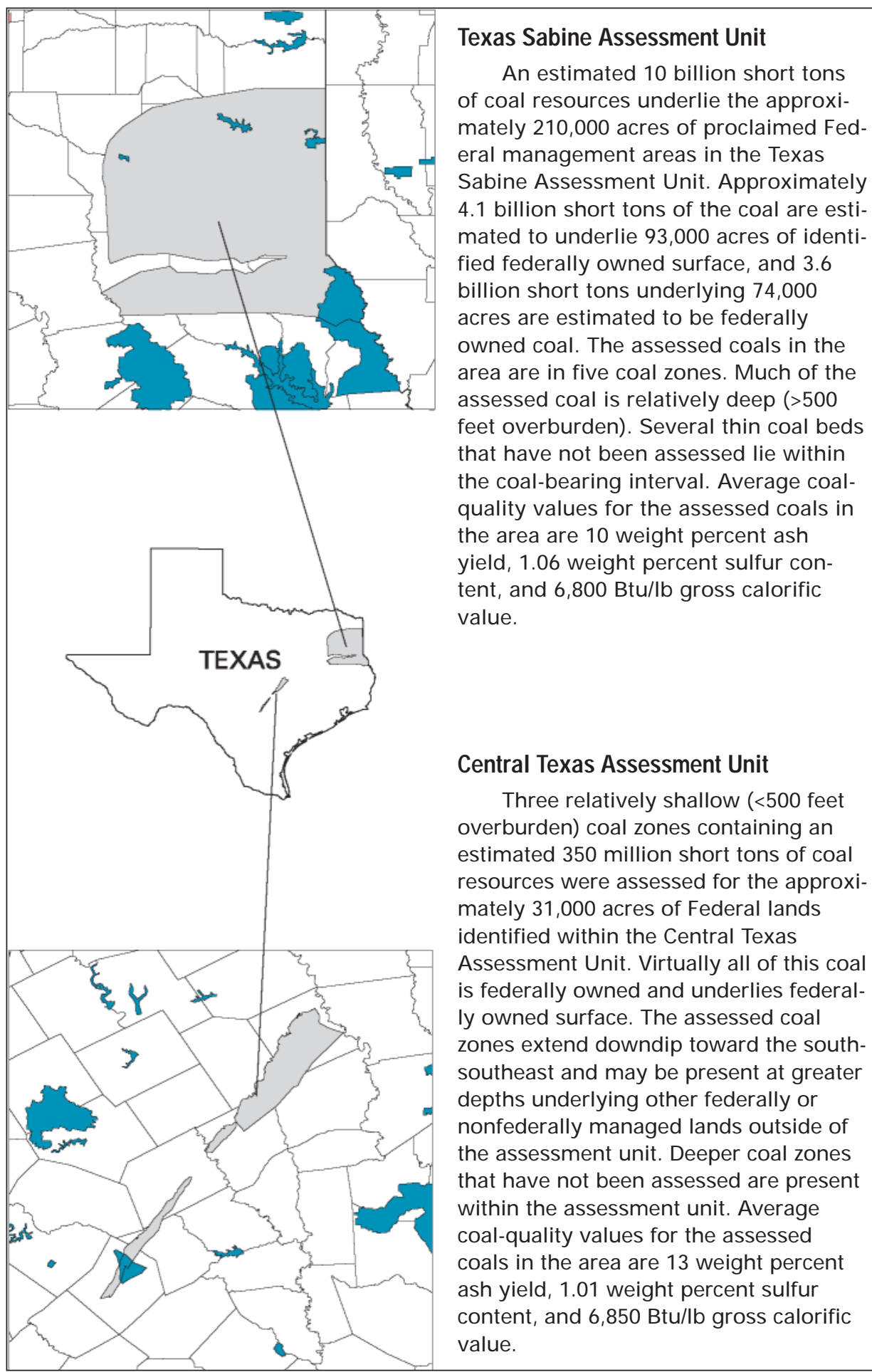

Figure 3. M aps of the Central Texas and Texas Sabine Assessment Units (gray) and surrounding counties showing the distribution of Federal lands (turquoise). Coal-quality data are given on an as-received basis. Btu/lb, British thermal units per pound. Tonnages are shown to tw 0 significant figures; totals in text do not add due to rounding. approximately 6.2 percent of the total coal estimated for the Gulf of Mexico Coastal Plain component of the NCRA. Approximately 4.4 billion short tons of this is estimated to underlie federally owned surface, of which approximately 4 billion short tons is federally owned coal. No Federal lands have been identified within the two other Gulf Coast assessment units: the Northeast Texas Assessment Unit and the Louisiana Sabine Assessment Unit.

\section{Texas Sabine Assessment Unit} of coal resources underlie the approximately 210,000 acres of proclaimed FedSabine Assessment Unit. Approximately 4.1 billion short tons of the coal are estified federally owned surface, and 3.6 billion short tons underlying 74,000 be federally area are in five coal zones. Much of the assessed coal is relatively deep $(>500$ that have not been assessed lie within the coal-bearing interval. Average coalcent sulfur content, and 6,800 Btu/lb gross calorific value.

Three relatively shallow $(<500$ feet overburden) coal zones containing an estimated 350 million short tons of coal resources were assessed for the approximately 31,000 acres of Federal lands identified within the Central Texas Assessment Unit. Virtually all of this coal ly owned surface. The assessed coal zones extend downdip toward the southoutheater the assessment unit. Deeper coal zones assesed are present coal-quality values for the assessed coals in the area are 13 weight percent content, and 6,850 Btu/lb gross calorific value.

\section{Conclusions}

About 6 percent of the total coal resource that was selected for assessment in the Gulf of Mexico Coastal Plain region of the NCRA project underlies federally proclaimed management areas. Of the approximately 11 billion short tons of coal in this category, approximately 37 percent are estimated to be federally owned. Much of the coal in these categories may not be available for mining, and much of it is probably not economically recoverable. The dispersed nature of Federal holdings, the complicated nature of surface and mineral estate ownership, and the existence of various legal and technological restrictions may remove a significant portion of this coal resource from consideration for development. Continuing work by USGS scientists suggests that potentially viable energy resources of coal-bed methane are present within both Federal and non-Federal areas of the Gulf of Mexico Coastal Plain coal-bearing region.

-Alex W. Karlsen, John R. SanFilipo, and Peter D. Warwick

\section{References}

Gulf of Mexico Coastal Plain Coal Region Assessment Team, in press, 2000 Resource assessment of selected coal beds and zones in northeastern and central Texas and the Sabine Uplift region of Texas-Louisiana: U.S. Geological Survey Professional Paper 1625-E, CD-ROM.

U.S. Geological Survey, 2000, Federal and Indian lands: Reston, Va., National Atlas of the United States. (Available online at http://www.nationalatlas.gov/fedlandsm.html.)

Wood, G.H., Jr., Kehn, T.M., Carter, M.D., and Culbertson, W.C., 1983, Coal resource classification system of the U.S. Geological Survey: U.S. Geological Survey Circular 891, 65 p. (Available online at http://energy. er.usgs.gov/products/papers/C891/index.htm.)

For more information on coal underlying Federal lands within the Gulf of Mexico Coastal Plain, please contact:

John R. SanFilipo

U.S. Geological Survey

956 National Center

Reston, VA 20192

Telephone: 703-648-6436

Fax: 703-648-6419

E-mail: jsan@usgs.gov

For more information on the National Coal Resource Assessment, Gulf of Mexico Coastal Plain, please contact:

Peter D. Warwick

U.S. Geological Survey

956 National Center

Reston, VA 20192

Telephone: 703-648-6469

Fax: 703-648-6419

E-mail: pwarwick@usgs.gov

Web: http://energy.er.usgs.gov/ncra/ 